\title{
Our Experience with Patients Diagnosed with Ischemic Colitis by Colonoscopy
}

\section{Kolonoskopide İskemik Kolit Tespit Edilen Hastalar ile Deneyimimiz}

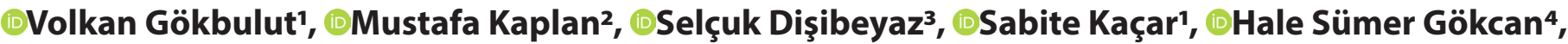 (D) Püren Gökbulut ${ }^{5}$, Đillyas Tenlik', DAdem Aksoy6}

\author{
'Ankara City Hospital, Department of Gastroenterology, Ankara, Turkey \\ ${ }^{2}$ Kayseri Memorial Hospital, Department of Gastroenterology, Kayseri, Turkey \\ ${ }^{3}$ Osmangazi University Faculty of Medicine, Department of Gastroenterology, Eskisehir, Turkey \\ ${ }^{4}$ Ankara University Faculty of Medicine, Department of Gastroenterology, Ankara, Turkey \\ ${ }^{5}$ Ankara Training and Research Hospital, Department of Endocrinology and Metabolic Diseases, Ankara, Turkey \\ ${ }^{6}$ Çankırı State Hospital, Department of Gastroenterology, Çankırı, Turkey
}

\begin{abstract}
Aim: Ischemic colitis (IC) is one of the most common causes of lower gastrointestinal bleeding, especially in patients over 60 years of age. In this study, we investigated the clinical and demographic characteristics of patients with IC detected by colonoscopy.

Material and Method: This study was conducted retrospectively by examining the records of patients who underwent colonoscopy for various reasons between January 2014 and December 2017. Patients with an IC pre-diagnosis in the colonoscopy reports were included in the study. A total of 130 patients were found; 18 patients were excluded from the study due to lack of data and the study was conducted with 112 patients.

Results: Definitive IC was diagnosed in 56 of the 112 patients who had a preliminary diagnosis by colonoscopy $(50 \%)$. The average age of patients diagnosed with definitive IC was 68; 30 were male and 26 were female. IC patients presented to the hospital with complaints of abdominal pain, hematochezia, diarrhea, and fever. IC most frequently affected the left colon. In the Doppler findings of patients with IC, all mesenteric vessels and aortas were normal in the large majority of patients (70\%). When predisposing factors that may cause IC were examined, hypertension was observed in $59 \%$ of patients, coronary artery disease in $59 \%$, diabetes mellitus in $21 \%$, and heart failure in $18 \%$. The vast majority of patients improved with medical therapy (89\%). Six patients underwent surgery for colon resection (11\%); 4 of these patients recovered but 2 died due to extensive thromboembolic disease and associated extensive ischemia (4\%).

Conclusion: IC is a disease that presents with symptoms such as bloody diarrhea and abdominal pain, especially in elderly male patients with predisposing risk factors. It is frequently seen in the left colon, responds well to medical treatment, and should be considered in every patient with acute diarrhea and abdominal pain.
\end{abstract}

Keywords: Ischemic colitis, colonoscopy, lower gastrointestinal bleeding, bloody diarrhea

\section{Öz}

Amaç: Iskemik kolit (IK) özellikle 60 yaş üstündeki hastalarda alt gastrointestinal kanamanın en sık görülen sebeplerinden biridir. Bu çalışmada kolonoskopide IK tespit edilen hastalarının klinik ve demografik özelliklerini araştırdık.

Gereç ve Yöntem: Bu çalışma Ocak 2014-Aralık 2017 tarihleri arasında çeşitli sebeplerle kolonoskopi yapılan hastaların hasta kayıtları incelenerek retrospektif olarak yapılmışıır. Kolonoskopi raporlarında IK ön tanısı olan hastalar çalışmaya alınmıştı. Toplan 130 hasta bulunmuş, 18 hasta veri eksikliği nedeniyle çalışmadan dışlanmış ve çalışma 112 hasta ile yapılmıştır.

Bulgular: Kolonoskopide IK ön tanısı olan 112 hastanın 56'sında kesin IK tanısı konulmuştur (\%50). Kesin IK tanısı alan hastaların yaş ortalaması 68 olup hastaların 30'u erkek, 26'sı ise kadın idi. İK hastalarının en sık karın ağrısı, hematokezya, ishal ve ateş şikayeti ile hastaneye başvurduğu görülmüştür Iskemik kolitin en sık sol kolonu tuttuğu görülmüştür. IK tanılı hastaların doppler bulgularında hastaların büyük çoğunluğunda tüm mezenter damarlar ve aort normaldi (\%70). IK'e sebep olabilecek predispozan faktörler incelendiğinde hastaların \%59'unda hipertansiyon, \%59'unda koroner arter hastalığı, \%21'inde diyabetes mellitus ve \%18'inde kalp yetmezliği izlendi. Hastaların büyük çoğunluğu medikal tedavi ile düzelmiştir (\%89). 6 hasta kolon rezeksiyonu için cerrahiye verilmiş (\%11), bu hastalardan 4 'ü iyileşmiş ancak iki hasta yaygın tromboembolik durum ve buna bağlı geniş iskemi nedeniyle exitus olmuştur (\%4).

Sonuç: İK özellikle predispozan risk faktörlerinin olduğu yaşlı erkek hastalarda kanlı ishal ve karın ağrısı ile semptom veren, sıklıkla sol kolonu tutan ve medikal tedaviye iyi yanıt veren bir hastalık olup akut ishal ve karın ağrısı olan her hastada akla gelmelidir.

Anahtar kelimeler: İskemik kolit, kolonoskopi, alt gastrointestinal kanama, kanlı ishal 


\section{INTRODUCTION}

Decreased intestinal blood flow due to arterial or venous occlusion and arterial vasospasm causes intestinal ischemia. [1] Ischemic colitis (IC) (or colonic ischemia) is the form of intestinal ischemia affecting the large intestine. ${ }^{[2]}$ It is one of the most common causes of lower gastrointestinal bleeding and bloody diarrhea, especially in patients over the age of $60 .{ }^{[3]}$ Endoscopic involvement can range from superficial damage to the mucosa and submucosal layer to full thickness necrosis of the colon wall. Most attacks are temporary and resolve spontaneously, but severe disease may result in necrosis. ${ }^{[4]}$ The disease affects elderly patients in particular and both sexes equally. Its classic clinical presentation includes abdominal pain, diarrhea, and rectal bleeding..$^{[5]}$ Numerous predisposing factors have been demonstrated to trigger IC. The best known of these are diabetes mellitus (DM), coronary artery disease (CAD), hypertension (HT), and thromboembolic events. ${ }^{[6,7]}$ IC can be confused with many diseases, especially inflammatory bowel diseases, due to its location and clinical presentation. [8] Often other diagnoses can be made in patients who are considered to have IC by colonoscopy. In the treatment of IC, the vasoconstrictive agents taken by patients should be discontinued and the patient should undergo bowel rest. If the patient has symptoms of ileus, a nasogastric tube should be inserted. Most patients receive medical treatment first, but in cases in which no benefit has been achieved surgery may be required. ${ }^{[9,10]}$ In the literature, studies on this subject are limited. In addition to the compatibility between the colonoscopic view and the final diagnosis, the effectiveness of medical treatment is not fully known. In the present study, we investigated the clinical and demographic characteristics and treatment responses of IC patients in addition to other diagnoses in patients with IC by colonoscopy.

\section{MATERIAL AND METHOD}

This study was carried out retrospectively by examining the records of patients who underwent colonoscopy for various reasons in the Gastroenterology Clinic of our hospital between January 2014 and December 2017. Patients with a pre-diagnosis or definitive diagnosis of IC in their colonoscopy reports were included in the study. A total of 130 patients were found; 18 patients were excluded from the study due to lack of data and the study was conducted with 112 patients. IC was diagnosed using a combination of clinical, endoscopic, radiological, and pathological findings by two experienced gastroenterologists. The study then continued with IC patients. The patients' complaints at presentation, predisposing factors, demographic characteristics, and laboratory results were recorded from their files. The colonoscopy findings of the patients were examined and the locations of involvement and endoscopic findings were noted. Biopsies were taken from all patients for pathological diagnosis and all patients were examined by Doppler ultrasonography for vascular pathologies. The oral intake of patients with suspected IC was discontinued. Intravenous fluid support and broadspectrum antibiotic therapy were initiated. Patients who were unresponsive to treatment and had widespread necrotic ischemia or peritonitis at first admission were referred for surgery. The statistical evaluation was performed using the Statistical Package for the Social Sciences (SPSS) for Windows 20 (IBM SPSS Inc., Chicago, IL, USA). The normality of the data distribution was evaluated by the KolmogorovSmirnov test. Among the numerical variables, those with normal distribution are shown as mean \pm standard deviation, and those without normal distribution are shown as median (min-max). Categorical variables are expressed as numbers and percentages. Since the study was retrospective, written consent was not obtained from the patients. The study was conducted in accordance with the ethical standards specified in the 1964 Declaration of Helsinki. In our study, research and publication ethics were followed and the rules were followed. Ethical approval was taken from Ethics Committee of Turkey Yüksek İhtisas Training and Research Hospital (Date: 07.05.2018, Decision No: 39).

\section{RESULTS}

Our study was conducted with 112 patients who were thought to have been pre-diagnosed with IC by colonoscopy. The average age of the patients was 64 and 76 were male and 36 were female. In the final examination, 56 of these patients were shown to have IC (50\%). Of the remaining 56 patients, 23 of them had nonspecific colitis (20\%), 12 ulcerative colitis (11\%), 8 Crohn's disease (7\%), 6 colon adenocarcinoma (5\%), 3 colonic lymphoma (3\%), 2 infectious colitis (2\%), and 2 sigmoid volvulus (2\%). The data of the patients evaluated with a pre-diagnosis of IC are given in Table 1.

\begin{tabular}{lc}
\hline \multicolumn{2}{l}{ Table 1. Patients evaluated with ischemic colitis prediagnosis } \\
\hline & $\mathbf{n}(\%)$ \\
\hline Gender (Male / Famale) & $76(68 \%) / 36(32 \%)$ \\
Age (Avg.) & $64 \pm 8.4$ \\
Definitive diagnosis of ischemic colitis & $56 / 112(50 \%)$ \\
Definitive diagnoses other than ischemic colitis & \\
Non-specific colitis & $23(20 \%)$ \\
Ulcerative colitis & $12(11 \%)$ \\
Crohn's disease & $8(7 \%)$ \\
Colon adenocarcinoma & $6(5 \%)$ \\
Colonic lymphoma & $3(3 \%)$ \\
Infectious colitis & $2(2 \%)$ \\
Sigmoid volvulus & $2(2 \%)$ \\
\hline
\end{tabular}

The 56 patients diagnosed with definite IC had an average age of 68 and 30 of them were male and 26 were female. IC patients were most frequently admitted to hospital with abdominal pain and less frequently with hematochezia, diarrhea, and fever. It was found that IC most commonly affects the sigmoid colon and descending colon, and less frequently the splenic flexure, rectum, transverse colon, 
hepatic flexure, ascending colon, and cecum, respectively. When the endoscopic findings were examined, it was observed that the majority of the patients had hyperemia, edema, and ulcers, and less frequently fragility, loss of the typical vascular pattern, hemorrhage, ecchymosis, stenosis, granularity, and necrosis. The demographic and clinical characteristics of the patients with IC are given in Table 2.

When the patients who were biopsied with the prediagnosis of IC and later diagnosed with definite IC were

Table 2. Demographic and clinical characteristics of patients diagnosed with ischemic colitis

\begin{tabular}{|c|c|}
\hline & n (\%) \\
\hline Gender (Male / Famale) & $30(54 \%) / 26(46 \%)$ \\
\hline Age (Avg.) & $68 \pm 7.5$ \\
\hline \multicolumn{2}{|l|}{ Symptoms } \\
\hline Abdominal pain & $49(88 \%)$ \\
\hline hematochezia & $30(54 \%)$ \\
\hline Diarrhea & $11(20 \%)$ \\
\hline Fever & $11(20 \%)$ \\
\hline \multicolumn{2}{|l|}{ Disease Involvement } \\
\hline Rectum & $26(46 \%)$ \\
\hline Sigmoid colon & $44(79 \%)$ \\
\hline Descending colon & $40(71 \%)$ \\
\hline Splenic flexure & $31(55 \%)$ \\
\hline Transverse colon & $19(34 \%)$ \\
\hline Hepatic flexure & $7(13 \%)$ \\
\hline Ascending colon & $4(7 \%)$ \\
\hline Cecum & $4(7 \%)$ \\
\hline \multicolumn{2}{|l|}{ Endoscopic Findings } \\
\hline Hyperemia & $45(80 \%)$ \\
\hline Edema & $44(79 \%)$ \\
\hline Ulcer & $34(61 \%)$ \\
\hline Fragility & $25(45 \%)$ \\
\hline loss of the typical vascular pattern & $22(39 \%)$ \\
\hline Haemorrhage & $13(23 \%)$ \\
\hline Ecchymosis & $13(23 \%)$ \\
\hline Narrowness & $8(14 \%)$ \\
\hline Granularity & $7(13 \%)$ \\
\hline Necrosis & $4(7 \%)$ \\
\hline \multicolumn{2}{|l|}{ Biopsy results } \\
\hline Ischemic colitis & $28(50 \%)$ \\
\hline Non-specific colitis & $18(32 \%)$ \\
\hline Focal active colitis & $7(13 \%)$ \\
\hline Chronic active colitis & $3(5 \%)$ \\
\hline \multicolumn{2}{|l|}{ Doppler findings } \\
\hline Normal vascular flow & $39(70 \%)$ \\
\hline Thromboembolism & $9(16 \%)$ \\
\hline Calcification-plaque in the aorta & $4(7 \%)$ \\
\hline Aortic Aneurysm & $3(5 \%)$ \\
\hline Budd chiari syndrome & $2(4 \%)$ \\
\hline SMA stenosis & $4(7 \%)$ \\
\hline Stenosis in the celiac artery & $2(4 \%)$ \\
\hline
\end{tabular}

examined, the biopsy result was compatible with IC in 28 patients (50\%), with non-specific colitis in 18 patients $(32 \%)$, with focal active colitis in 7 patients $(13 \%)$, and with 3 chronic active colitis in 3 patients (5\%). All mesentery vessels and aortas were normal in the majority of patients (70\%) in the Doppler findings of patients with a diagnosis of IC. Thrombus in the mesentery vessels or aorta was detected in $16 \%$ of the patients, aortic aneurysm in $5 \%$, and plaque and thickening in the aorta in $5 \%$. In addition, stenosis was found in the superior mesenteric artery in $7 \%$ of the patients and in the two celiac arteries in $4 \%$. In the examination, chronic thrombus in the hepatic veins was observed in two patients (4\%). When the predisposing factors that may cause IC were examined, 59\% of them had hypertension and 59\% had coronary artery disease. In addition, diabetes mellitus was observed in 12 patients (21\%), heart failure in 10 patients (18\%), and atrial fibrillation in 5 patients (9\%). It was learned that 4 patients had experienced a condition with hypotension in the previous 6 months (7\%). Furthermore, 4 patients had a history of deep vein thrombosis or pulmonary thromboembolism in the previous 6 months (7\%). Four patients had chronic renal failure (7\%) and one patient had underlying pancreatic cancer (2\%). It was learned that three patients underwent aortic valve replacement $(5 \%)$ and two patients had mitral valve replacement (5\%). The predisposing factors in the patients with IC are given in Table $\mathbf{3}$.

When the laboratory results of the patients were examined, the mean white blood cell value of the patients was $13.1 \times$ $103 / \mu \mathrm{L}$, the mean hemoglobin value was $12.8 \mathrm{~g} / \mathrm{dL}$, and the mean C-reactive protein was $90 \mathrm{mg} / \mathrm{L}$. The other laboratory values were within the normal limits. The laboratory results of the patients are given in Table 4.

The treatment endpoints are given in Table 5. The majority of patients recovered with medical therapy (89\%). Six patients underwent surgery for colon resection (11\%); 4 of these patients recovered, but 2 died due to extensive thromboembolic disease and related extensive ischemia (4\%).

\begin{tabular}{lc} 
Table 3. Predisposing factors in ischemic colitis patients \\
\hline Hypertension & $\mathbf{n ~ ( \% )}$ \\
Coronary artery disease & $33(59 \%)$ \\
Diabetes mellitus & $33(59 \%)$ \\
Heart failure & $12(21 \%)$ \\
Atrial fibrillation & $10(18 \%)$ \\
Chronic renal failure & $5(9 \%)$ \\
Shock-hypotension & $4(7 \%)$ \\
History of deep vein thrombosis or pulmonary embolism & $4(7 \%)$ \\
Aortic valve replacement & $4(7 \%)$ \\
Mitral valve replacement & $3(5 \%)$ \\
Pancreatic cancer & $2(4 \%)$ \\
Heart transplant & $1(2 \%)$ \\
Primary pulmonary hypertension & $1(2 \%)$ \\
Operated aortic aneurysm & $1(2 \%)$ \\
\hline
\end{tabular}




\begin{tabular}{lc} 
Table 4. Laboratory findings of ischemic colitis patients \\
White blood cell count $\left(\times 10^{3} / \mathrm{uL}\right)$ & 13.1 \\
Hemoglobin (g/dl) & 12.8 \\
Platelet $\left(\times 10^{3} / \mathrm{uL}\right)$ & 210 \\
INR & 1.25 \\
AST (U/L) & 23 \\
ALT (U/L) & 16 \\
LDH (U/L) & 245 \\
Creatinine (mg/dL) & 1.21 \\
Amylase (U/L) & 65 \\
C-reactive protein (mg/L) & 90 \\
\hline INR: international normalized ratio, AST: aspartate aminotransferase, ALT: alanine transaminase, LDH: \\
\hline
\end{tabular}

\begin{tabular}{lc}
\hline Table 5. Treatment endpoints & $\mathbf{n}(\%)$ \\
\hline Response to medical therapy & $50 / 56(89 \%)$ \\
Surgery requirement & $6 / 56(11 \%)$ \\
Exitus & $2(4 \%)$ \\
\hline
\end{tabular}

\section{DISCUSSION}

In the present study, patients with suspected IC on colonoscopy were examined and it was found that only half of those who were considered to have IC actually had it. It was also seen that IC is an important cause of lower gastrointestinal bleeding, especially in elderly patients, and often affects the left colon. It was found that it is difficult to differentiate from infectious colitis or inflammatory bowel diseases in terms of endoscopic findings. Although arterial or venous occlusion is the most common etiology, Doppler findings are normal in most patients. It was seen that the most important risk factors for the disease are underlying diseases such as DM, HT, and CAD. In addition, it was understood in the present study that IC patients respond very well to medical treatment.

In our study, IC was diagnosed based on a detailed histological, radiological, and clinical evaluation in only half of the patients who were considered to have IC as a result of colonoscopy. We think that the main reason for this situation is that the endoscopic appearance of IC is very similar to that of inflammatory bowel diseases and infectious colitis. In previous studies, it was found that these diseases were difficult to differentiate between. It has been stated that pathological examination, clinical examination, and imaging are essential for differentiation. ${ }^{[11]}$ Compared to IC patients, patients with ulcerative colitis have a longer course of the disease and a lower incidence of cardiovascular comorbidity. It is important to examine the underlying diseases in detail in these patient groups. Another condition that needs to be differentiated from IC is the nonspecific colitis picture that develops mostly due to infectious causes or the intake of nonsteroidal antiinflammatory drugs. As a matter of fact, nonspecific colitis was detected in a significant portion of the patients who did not develop IC in our study. Other important differential diagnoses in our study were Crohn's disease, malignancies, and volvulus. Imaging methods are recommended, especially when the differential diagnosis with Crohn's disease is insufficient. ${ }^{[12]}$
IC was found to be more common in elderly patients in our study. Most of the previous studies with IC have shown that patients are elderly and IC is an important cause of lower gastrointestinal bleeding in elderly patients. ${ }^{[4,6]}$ In our study, IC was observed to occur more frequently in men. There are conflicting results in previous studies on this subject. Choi et al. showed that IC is more common in women and severe IC is more common in men. ${ }^{[13]}$ In the study by Medina et al., which included 53 patients, it was observed that 30 of the patients were male. $^{[14]}$

In our study, in accordance with the literature, the most common clinical findings were abdominal pain, diarrhea, and hematochezia. In a previous study, it was shown that IC was the cause in almost one fifth of the patients who underwent colonoscopy due to lower gastrointestinal bleeding. ${ }^{[15]}$ In another case-control study, it was shown that abdominal pain may be associated with IC, especially in the presence of hemodialysis, diabetes mellitus, hypertension, and hypoalbuminemia in elderly patients presenting with lower abdominal pain, with or without lower GIS bleeding. ${ }^{[16]}$ In our study, it was thought that the cause of fever in some patients might be systemic infection developing secondary to IC invasion.

In our study, it was shown once again that IC mostly affects the left colon. As is known, mesenteric arteries nourish the colon by forming anastomoses directly or with other vessels. Ischemia is more common in these anastomoses due to insufficient perfusion of the rectosigmoid and sphenic flexure segments. When our study findings are examined, we see that the entire left colon is usually involved instead of an isolated area in the left colon. Right colon involvement is very low. It is also known that IC involving the right colon has a more severe course. ${ }^{[17]}$ In the study conducted by Sun et al., right-sided IC, shock, or arterial hypotension $(<90 \mathrm{mmHg}$ ) and peritonitis findings were shown as the most important markers in determining the severity of IC. In fact, the right colon involvement IC in both patients who died in our study supports the above findings.

When the endoscopies of IC patients are examined, it is seen that nonspecific hyperemia, edema, and ulcers are observed in most patients. The same findings can be seen in many diseases, especially ulcerative colitis. Additionally, a single, linear ulcer running along the anti-mesenteric colonic wall, the single-stripe sign, favors the diagnosis of IC. Zuckerman et al. reported the presence of the colonic single-stripe sign greater than $5 \mathrm{~cm}$ in length, with $89 \%$ of the lesions identified in an isolated segment of the left colon. A preceding ischemic event was noted in $62 \%$ of these patients. ${ }^{[18,19]}$ Biopsy is recommended because endoscopic appearance may be insufficient for diagnosis. However, there may be situations in which the biopsy is nondiagnostic. ${ }^{[20]}$ Various types of colitis may have similar appearances. However, the combination of histopathology, clinical, and endoscopic data allows accurate classification in most cases. ${ }^{[21]}$ In fact, when the patients who 
were finally diagnosed with IC were examined in our study, it was seen that the biopsy results of half of the patients were not typical for IC. For this reason, it is important that the diagnosis of IC is made by experienced people based on a histological evaluation and taking into account the imaging and clinical conditions. In our study, it was observed that the vessels are patent in most patients with imaging methods. That suggests that this situation may be due to temporary occlusion of the underlying predisposing factors rather than complete occlusion of the vessels feeding the colon. Sometimes, imaging methods are insufficient to show arterial or venous occlusion. In such cases, angiography is considered the gold standard method. However, it is not generally preferred because it is an invasive procedure.

When the risk factors for IC were examined in our study, the most frequent findings were $\mathrm{HT}, \mathrm{CAD}, \mathrm{DM}$, heart failure, and atrial fibrillation. In the study by Choi et al., the predisposing risk factors were very similar to our findings. ${ }^{[13]}$ In their study, in contrast to ours, it was stated that stroke, hyperlipidemia, and thyroid diseases also pose risks for the development of IC. In another study, almost $75 \%$ of the patients had HT; DM, CAH, and stroke have an important place in etiology; and it was emphasized that peripheral artery disease and COPD should be considered risk factors. ${ }^{[22]}$

When the laboratory results of our patients were examined, it was seen that CRP and white cell values increased in patients due to the underlying disease and possible secondary infection, and mild anemia developed due to bloody diarrhea and hematochezia. Some of our patients had symptoms of organ failure due to severe IC and complications. However, our study showed that parameters such as LDH and amylase, which are generally used to show ischemia, do not increase in correlation with the disease, as expected.

Overall $89 \%$ of the patients in our study recovered after medical treatment. In previous studies, it was emphasized that the main treatment for IC is conservative medicine, but surgery should be performed in cases of complications such as peritonitis or necrosis. ${ }^{[2,9]}$ In medical treatment, it is very important to correct the underlying disease and to eliminate the drugs and predisposing factors that will cause ischemia. Early antibiotic therapy (combination of quinolone and metronidazole) has been found to be very beneficial, especially in patients with bloody diarrhea and high white blood cell and CRP values. The most important reason for failure in treatment is delay in diagnosis, advanced age of the patients, the severity of the underlying disease, and the patients' additional comorbid diseases. ${ }^{[23,24]}$

In our study, the mortality rate was quite low (4\%). There are different rates in the literature in terms of mortality. The mortality rate was $11 \%$ in the study by Brandt et al. ${ }^{[22]}$ In another study, a mortality rate of around $29 \%$ was found. ${ }^{[25]}$ In these studies, it was shown that mortality is significantly increased especially with right colon or pancolonic involvement. The main reason for such obvious differences between studies is the difference in the patients included. We think that especially the $29 \%$ mortality rate may be related to the advanced age patient group including multiple risk factors in the study.

The most important limitation of our study is the small number of patients. In addition, our information regarding the long-term follow-up and recurrence of the patients due to insufficient follow-up data is lacking.

In conclusion, IC presents with bloody diarrhea and abdominal pain, especially in elderly male patients with predisposing risk factors. It is a disease that involves the left colon and responds well to medical treatment and should be considered in every patient with acute diarrhea and abdominal pain.

\section{ETHICAL DECLARATIONS}

Ethics Committee Approval: Ethical approval was taken from Ethics Committee of Turkey Yüksek intisas Training and Research Hospital (Date: 07.05.2018, Decision No: 39).

Informed Consent: Because the study was designed retrospectively, no written informed consent form was obtained from patients.

Referee Evaluation Process: Externally peer-reviewed. Conflict of Interest Statement: The authors have no conflicts of interest to declare.

Financial Disclosure: The authors declared that this study has received no financial support.

Author Contributions: All of the authors declare that they have all participated in the design, execution, and analysis of the paper, and that they have approved the final version.

\section{REFERENCES}

1. Renner $\mathrm{P}$, Kienle $\mathrm{K}$, Dahlke $\mathrm{MH}$, et al. Intestinal ischemia:current treatment concepts. Langenbecks Arch Surg 2011;396 (1):3-11.

2. Misiakos EP, Tsapralis D, Karatzas T, et al. Advents in the Diagnosis and Management of Ischemic Colitis. Front Surg 2017;4:47.

3. Fitzgerald JF, Hernandez LO, III. Ischemic colitis. Clin Colon Rectal Surg 2015: 28:93-8.

4. Yngvadottir Y, Karlsdottir BR, Hreinsson JP, et al. The incidence and outcome of ischemic colitis in a population-based setting. Scand J Gastroenterol 2017; 52:704-10.

5. Cruz C, Abujudeh HH, Nazarian RM, Thrall JH. Ischemic colitis:spectrum of CT findings, sites of involvement and severity. Emerg Radiol 2015;22:35765.

6. Longstreth GF, Yao JF. Epidemiology, clinical features, high risk factors, and outcome of acute large bowel ischemia. Clin Gastroenterol Hepatol 2009; 7:1075-80.

7. Noh M, Yang SS, Jung SW, Park JH, Im YC, Kim KY. Poor prognostic factors in patients who underwent surgery for acute non-occlusive ischemic colitis. World J Emerg Surg 2015; 10:12.

8. Mohanapriya T, Balaji Singh K, Arulappan T, Shobhana R. Ischemic colitis Indian J Surg 2012; 74:396-400.

9. Washington C, Carmichael JC. Management of ischemic colitis. Clin Colon Rectal Surg 2012; 25:228-35.

10. Moninska P, Fichna J. Ischemic colitis:current diagnosis and treatment Curr Drug Targets 2015;16:209-18.

11. Lyu G, Li J, Liu AL, Zhao YX, Yang H, Qian JM. Zhonghua Nei Ke Za Zhi 2016;55(6):466-9. 
12. Chen M, Remer EM, Liu X, Lopez R, Shen B. Identification of the distinguishing features of Crohn's disease and ischemic colitis using computed tomographic enterography. Gastroenterol Rep (Oxf) 2017;5(3):219-25.

13. Choi SR, Jee SR, Song GA, et al. Predictive Factors for Severe Outcomes in Ischemic Colitis. Gut Liver 2015;9(6):761-6.

14. Medina C, Vilaseca J, Videla S, Fabra R, Armengol-Miro JR, Malagelada JR. Outcome of patients with ischemic colitis:review of fifty-three cases. Dis Colon Rectum 2004;47(2):180-4.

15. Hreinsson J P, Gumundsson S, Kalaitzakis E, Björnsson E S. Lower gastrointestinal bleeding:incidence, etiology, and outcomes in a population-based setting. Eur J Gastroenterol Hepatol 2013;25(1):37-43.

16. 16 Park C J, Jang M K, Shin W G. et al. Can we predict the development of ischemic colitis among patients with lower abdominal pain? Dis Colon Rectum 2007;50(2):232-8.

17. Sun D, Wang C, Yang L, Liu M, Chen F. The predictors of the severity of ischaemic colitis:a systematic review of 2823 patients from 22 studies. Colorectal Dis 2016;18(10):949-58.

18.Zuckerman GR, Prakash C, Merriman RB, Sawhney MS, DeSchryverKecskemeti K, Clouse RE. The colon single-stripe sign and its relationship to ischemic colitis. Am J Gastroenterol. 2003;98(9):2018-22.

19. Parikh MP, Satiya J, Berger-Saunderson M, Gupta NM, Sanaka MR. The Colonic Single Stripe Sign:A Case of Ischemic Colitis. Cureus. 2019;11(5):e4622.

20. Jessurun J. The Differential Diagnosis of Acute Colitis: Clues to a Specific Diagnosis. Surg Pathol Clin 2017;10(4):863-85.

21. Cerilli LA, Greenson JK. The differential diagnosis of colitis in endoscopic biopsy specimens:a review article. Arch Pathol Lab Med 2012;136(8):85464.

22. Brandt LJ, Feuerstadt P, Blaszka MC. Anatomic patterns, patient characteristics, and clinical outcomes in ischemic colitis:a study of 313 cases supported by histology. Am J Gastroenterol 2010;105(10):2245-53.

23. Beck DE, de Aguilar-Nascimento JE. Surgical management and outcome in acute ischemic colitis. Ochsner J 2011;11(3):282-5.

24. Rania $\mathrm{H}$, Mériam S, Rym E, et al. Ischemic colitis in five points:an update 2013. Tunis Med 2014;92(5):299-303.

25. Gilshtein $\mathrm{H}$, Hallon K, Kluger Y. Ischemic colitis caused increased early and delayed mortality. World J Emerg Surg 2018;13:31. 